\title{
PENGARUH BAURAN PEMASARAN (MARKETING MIX) TERHADAP KEPUTUSAN PEMBELIAN PADA PRODUK KARA SANTAN PT ENSEVAL PUTERA MEGATRADING, Tbk
}

\author{
Sylvia Shareen ${ }^{1}$ ), Nur Rahmah Andayani ${ }^{2}$ ) \\ 1) Prodi Administrasi Bisnis Terapan Politeknik Negeri Batam,email:sylviashareen.131193@gmail.com \\ 2) Prodi Administrasi Bisnis Terapan Politeknik Negeri Batam, email: nunun@ polibatam.ac.id
}

\begin{abstract}
This study aims to determine and analyze the influence of marketing mix which consists of product variables, prices, promotions, places, people, and the process of purchasing decisions on products Kara Santan PT. Enseval Putera Megatrading, Tbk simultaneously or partially. Population in this research is customer of PT. Enseval Megatrading Putera Tbk Batam Branch who had a history of purchases Kara Santan period in 2016. The analysis method used in this research is descriptive analysis and multiple regression analysis using SPSS 20. Hypothesis testing using T test and F test value of $\alpha=5 \%$. The results showed that in partial product, price, promotion, people, and processes of positive and significant influence on purchasing decisions, althought place have no effect and significant impact on purchasing decisions, and simultaneously all the variable positive and significant impact on purchasing decisions PT. Enseval Putera Megatrading, Tbk.
\end{abstract}

Keywords: Product, Price, Promotion, Place, People, Process, Mix Marketing, Purchasing Decisions.

\section{abstrak}

Penelitian ini bertujuan untuk mengetahui dan menganalisis pengaruh bauran pemasaran (Marketing Mix) yang terdiri dari variabel produk, harga, promosi, tempat, orang, dan proses terhadap keputusan pembelian pada produk Kara Santan PT. Enseval Putera Megatrading, Tbk secara simultan maupun parsial. Populasi dalam penelitian ini adalah pelanggan PT. Enseval Putera Megatrading, Tbk Cabang Batam yang memiliki riwayat pembelian Kara Santan periode tahun 2016. Metode analisis yang digunakan dalam penelitian ini adalah analisis deskriptif dan analisis regresi berganda menggunakan program SPSS 20. Uji hipotesis menggunakan uji $\mathrm{T}$ dan uji $\mathrm{F}$ dengan nilai $\alpha=5 \%$. Dari hasil penelitian menunjukkan bahwa secara parsial variabel produk, harga, promosi, orang, dan proses berpengaruh positif dan signifikan terhadap keputusan pembelian, sedangkan variabel tempat tidak berpengaruh dan signifikan terhadap keputusan pembelian. Secara simultan semua variabel berpengaruh positif dan signifikan terhadap keputusan pembelian PT. Enseval Putera Megatrading, Tbk.

Kata kunci : Produk, Harga, Promosi, Tempat, Orang, Proses, Marketing Mix, Bauran Pemasaran, Keputusan Pembelian 


\section{PENDAHULUAN}

Persaingan dunia usaha sekarang semakin kompetitif. Setiap perusahaan saling bersaing untuk mendapatkan pelanggan agar dapat membeli produk yang mereka tawarkan, PT Enseval Putera Megatrading, Tbk (EPM) yang memiliki 46 cabang di seluruh Indonesia adalah perusahaan farmasi multinasional yang bermarkas di Jakarta. Perusahaan ini didirikan tahun 1973 dan memproduksi berbagai macam barang farmasi dan cabang Batam didirikan pada tahun 2002 sebagai cabang ke 37 dari 46 cabang di Indonesia. Dalam perkembangannya, PT EPM tumbuh menjadi sebuah distributor umum, tidak hanya menyangkut produk farmasi, tetapi juga berbagai macam produk pelanggan, peralatan medis, bahkan berperan sebagai agen dan distributor bahan baku kimia untuk industri farmasi, kosmetik, dan makanan industri, salah satunya adalah produk kara santan yang akan menjadi fokus kita pada penelitian ini.

Menjadi perusahaan multinasional tidak menjamin keberhasilan setiap waktu, hal ini dapat dilihat dari munculnya perusahaan lokal maupun multinasional lainnya yang bersaing dan berlomba untuk mendapatkan pelanggan. Dilihat dari fenomena tersebut, dapat dikatakan bahwa persaingan perusahaan semakin ketat. Oleh karena itu, untuk mempertahankan dan menghadapi persaingan, perusahaan harus menerapkan perencanaan taktis untuk memenangkan pasar, salah satunya adalah dengan menggunakan konsep bauran pemasaran (marketing mix).

Marketing Mix adalah suatu strategi marketing yang menekankan bagaimana cara menjual produk seefektif mungkin. Menurut (Kotler \& Keller, 2009) menyatakan "Marketing Mix adalah kombinasi dari variabel atau kegiatan yang merupakan inti dari sistem pemasaran yaitu produk, harga, promosi, dan tempat. Dengan kata lain marketing mix adalah kumpulan variabel yang dapat digunakan oleh perusahaan untuk dapat mempengaruhi tanggapan pelanggan".

Keputusan pembelian merupakan proses dalam pembelian yang nyata, apakah membeli atau tidak (Dharmmesta \& Handoko, 2012). Dalam keputusan membeli barang, seringkali lebih dari dua pihak yang terlibat dalam proses pertukaran atau membelinya, umumnya ada lima macam peranan yang dapat dilakukan oleh seseorang yaitu : (1) Pencetus ide (initiator), (2) Pemberi pengaruh (influencer), (3) Pengambil keputusan (decider), (4) Pelanggan (buyer), dan yang terakhir adalah (5) Pemakai (user). Keputusan pembelian melewati lima tahapan, yaitu pengenalan masalah, pencarian informasi, evaluasi alternatif, keputusan membeli dan tingkah laku pasca pembelian (Kotler \& Keller, 2009).

Kara santan merupakan salah satu dari merek produk yang paling dicari oleh pelanggan. Hal ini memberikan kebanggaan tersendiri bagi perusahaan karena mampu menembus pasar utama dan bertahan hingga kini. Tetapi seperti kehidupan, roda tidak akan selamanya berada diatas, ada kalanya kita harus mempersiapkan diri dari kemungkinan terburuk yang bisa saja terjadi dikemudian hari, ditambah dengan telah munculnya beberapa merek santan praktis dari brand terkenal lainnya yang dapat menggeser penjualan.

Melihat masalah yang ada, maka peneliti akan melakukan survei untuk mengetahui pengaruh peran marketing mix yang ada di perusahaan terhadap intensitas keputusan pembelian oleh pelanggan. Survey akan dilakukan ke 167 toko yang memiliki histori pembelian dengan PT EPM untuk produk kara santan di wilayah Batam secara acak.

Berdasarkan penelitian terdahulu oleh Hariadi \& Martoadmodjo (2012), yang berjudul Pengaruh Produk, Harga, Promosi, dan Distribusi Terhadap Keputusan Pembelian Konsumen Pada Produk Projector Microvision, menyatakan bahwa produk, harga, promosi, dan distribusi secara simultan berpengaruh positif dan signifikan terhadap keputusan pembelian.

Mengingat hal ini sangat penting, maka penulis tertarik melakukan penelitian ilmiah dengan judul

$\begin{array}{lcr}\text { "PENGARUH } & \text { BAURAN } & \text { PEMASARAN } \\ \text { (MARKETING } & \text { MIX) } & \text { TERHADAP } \\ \text { KEPUTUSAN } & \text { PEMBELIAN } & \text { PADA } \\ \text { PRODUK KARA } & \text { SANTAN PT } & \text { ENSEVAL } \\ \text { PUTERA MEGATRADING, Tbk" (EPM). }\end{array}$




\section{KAJIAN PUSTAKA 1. Produk}

Segala sesuatu yang dapat ditawarkan kepada pasar untuk memuaskan suatu keinginan atau kebutuhan, termasuk barang fisik, jasa, pengalaman, acara, orang, tempat, properti, organisasi, informasi, dan ide (Kotler \& Keller, 2009).

Produk merupakan elemen penting dalam sebuah program pemasaran. Strategi produk dapat mempengaruhi strategi pemasaran lainnya. Pembelian sebuah produk bukan hanya sekedar untuk memiliki produk tersebut tetapi juga untuk memenuhi kebutuhan dan keinginan pelanggan.

\section{Harga}

Harga merupakan komponen yang berpengaruh langsung terhadap laba perusahaan (Tjiptono, 2008).

Harga adalah jumlah uang yang dibutuhkan untuk mendapatkan sejumlah kombinasi barang beserta pelayanannya (Sumarni \& Soeprihanto, 2010).

\section{Promosi}

Pada hakikatnya promosi adalah suatu bentuk komunikasi pemasaran. Komunikasi pemasaran adalah aktivitas pemasaran yang berusaha menyebarkan informasi, mempengaruhi/membujuk, dan/atau mengingatkan pasar sasaran atas perusahaan dan produknya agar bersedia menerima, membeli, dan loyal pada produk yang ditawarkan perusahaan yang bersangkutan (Tjiptono, 2008).

Media promosi yang dapat digunakan pada bisnis ini antara lain :

1) Periklanan,

2) Promosi penjualan,

3) Publisitas dan hubungan masyarakat, dan

4) Penjualan langsung.

\section{Tempat}

Saluran yang digunakan produsen untuk menyalurkan produk tersebut sampai kepada pelanggan (Sumarni \& Soeprihanto, 2010). Dari definisi diatas dapat diartikan bahwa saluran distribusi suatu barang adalah keseluruhan kegiatan atau fungsi untuk memindahkan produk disertai dengan hak pemiliknya dari produsen ke pelanggan akhir atau pemakai industri.

Distribusi berkaitan dengan kemudahan memperoleh produk di pasar dan tersedia saat pelanggan mencarinya. Distribusi memperlihatkan berbagai kegiatan yang dilakukan perusahaan untuk menjadikan produk atau jasa diperoleh dan tersedia bagi pelanggan sasaran.

\section{Orang}

Menurut Kotler (2008), Orang adalah proses seleksi, pelatihan, dan pemotivasian karyawan yang nantinya dapat digunakan sebagai pembedaan perusahaan dalam memenuhi kepuasan pelangan. Semua karyawan yang berhubungan dengan konsumen dapat disebut sebagai tenaga penjual. Dengan kata lain, dalam pengertian yang luas, pemasaran merupakan pekerjaan semua personel dalam perusahaan. Oleh karena itu penting kiranya semua perilaku karyawan harus diorientasikan kepada konsumen. Itu berarti perusahaan harus merekrut dan mempertahankan karyawan yang mempunyai skill, sikap, komitmen, dan kemampuan dalam membina hubungan baik dengan konsumen.

\section{Proses}

Menurut Kotler, 2008 Proses adalah "Semua prosedur aktual, mekanisme dan aliran aktivitas dengan mana produk disampaikan yang merupakan sistem penyajian atas operasi ". Elemen proses ini mempunyai arti suatu upaya perusahaan dalam menjalankan dan melaksanakan aktifitas untuk memenuhi kebutuhan dan keinginan konsumennya. Untuk perusahan, kerja sama antara pemasaran dan operasional sangat penting dalam elemen proses ini, terutama dalam melayani segala kebutuhan dan keinginan konsumen.

Proses merupakan faktor utama dalam bauran pemasaran jasa seperti pelanggan jasa akan sering merasakan sistem penyerahan jasa sebagai bagian dari jasa itu sendiri. Selain itu keputusan dalam manajemen operasi adalah sangat penting untuk suksesnya pemasaran jasa. Seluruh aktifitas kerja adalah proses, proses melibatkan prosedur-prosedur, tugastugas, mekanisme-mekanisme, aktifitasaktifitas dan rutinitas-rutinitas dengan apa produk (barang atau jasa) disalurkan ke pelanggan. Identitas manajemen proses sebagai aktifitas terpisah adalah prasyarat bagi perbaikan jasa. Pentingnya elemen proses ini khususnya dalam bisnis jasa disebabkan oleh persediaan jasa yang tidak dapat disimpan. 


\section{Keputusan Pembelian}

Keputusan pembelian merupakan proses dalam pembelian yang nyata, apakah membeli atau tidak. (Dharmmesta \& Handoko, 2012).

Dalam keputusan membeli barang, seringkali lebih dari dua pihak yang terlibat dalam proses jual beli. Umumnya ada lima macam peranan yang dapat dilakukan oleh seseorang yaitu : (1) Pencetus ide (initiator), (2) Pemberi pengaruh (influencer), (3) Pengambil keputusan (decider), (4) Pelanggan (buyer), dan (5) Pemakai (user).

Proses keputusan pembelian menurut Kotler \& Keller (2009) melalui lima tahap seperti terlihat pada Gambar di bawah ini:

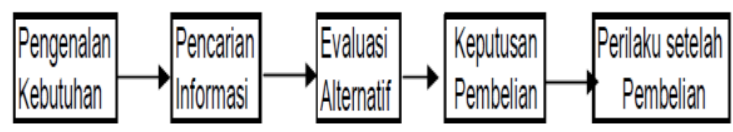

Model Proses pembelian (Kotler \& Keller, 2009)

Gambar memperlihatkan model tahapan dari proses pembelian. Pelanggan tersebut melalui lima tahap : pengenalan masalah, pencarian masalah, evaluasi alternatif, keputusan pembelian, dan perilaku setelah pembelian. Model ini menyiratkan bahwa pelanggan melalui lima tahap dalam membeli suatu produk. Tetapi hal ini tidak terjadi pada semua kasus terutama dalam pembelian dengan keterlibatan rendah. Pelanggan mungkin melewatkan atau mengulangi tahap-tahap tertentu. Namun demikian, kita akan menggunakan model Gambar karena model ini memasukkan semua perbandingan yang terjadi ketika pelanggan menghadapi pembelian baru dengan keterlibatan tinggi.

\section{METODE PENELITIAN}

\section{Rancangan Penelitian}

Penelitian ini menggunakan pendekatan kuantitatif, dimana menitikberatkan pada pengujian hipotesis dengan menggunakan data terukur sehingga diharapkan dapat ditarik suatu kesimpulan. Jenis penelitian ini adalah penelitian kausalitas yaitu penelitian yang berusaha untuk melihat apakah antara dua variabel atau lebih memiliki pengaruh atau tidak, berapa besarnya pengaruh, serta sejauh mana arah dari pengaruh tersebut.

Objek dalam penelitian ini adalah pelangganpelanggan atau pelanggan yang pernah membeli kara santan di PT EPM dan sekitarnya secara acak.

\section{Populasi dan Sampel}

Populasi merupakan objek atau subjek yang memenuhi kriteria tertentu yang telah ditentukan oleh peneliti. Menurut (Sugiyono, 2014) pengertian populasi adalah wilayah generalisasi yang terdiri atas obyek atau subyek yang mempunyai kualitas dan karakteristik tertentu yang ditetapkan oleh peneliti untuk dipelajari dan kemudian ditarik kesimpulan. Sehingga populasi dari penelitian ini adalah pelanggan PT EPM di Batam yang memiliki histori pembelian sejumlah 320 pelanggan.

Sampel adalah bagian dari jumlah dan karakteristik yang dimiliki oleh populasi tersebut (Sugiyono, 2014). Metode yang dipilih adalah sample random sampling, yang merupakan salah satu dari teknik probability sampling yang sampelnya diambil secara acak. Pemilihan metode ini didasarkan dengan pelanggan di enam daerah histori pembelian kara santan terbesar. Jumlah sampel penelitian sekaligus menjadi responden, yang diambil menurut Isaac dan Michael dengan tingkat kesalahan 5\% (Sugiono, 2008), terpilih sampel sebanyak 167 Pelanggan.

Teknik pengumpulan data yang digunakan dalam penelitain ini adalah dengan pengumpulan data secara langsung dan tidak langsung, melalui observasi, kuesioner dan dokumentasi.

Sumber dan jenis data yang digunakan adalah data primer dan data sekunder.

\section{Validitas dan Reliabilitas Validitas}

Uji validitas dimaksudkan untuk mengukur sejauh mana ketepatan alat ukur penelitian tentang isu atau arti yang sebenarnya diukur (Ghozali, 2011). Suatu instrumen dikatakan valid apabila mampu mengukur apa yang diinginkan serta dapat mengungkap data dari variabel yang diteliti dengan tepat. Uji validitas dilakukan dengan teknik validitas internal, yang dapat dicapai apabila ada kesesuaian antara bagian-bagaian instrumen dengan total instrumen secara keseluruhan. Tingkat signifikansi 0,05 sehingga apabila 
Sylvia \& Nur Rahmah, pengaruh bauran pemasaran (marketing mix) terhadap keputusan pembelian ....

angka korelasi yang diperoleh berada di atas nilai kritis maka item tersebut valid.

Dari hasil uji validitas yang dilaksanakan, pada Produk (X1), Harga (X2), Promosi (X.3), Tempat (X4), Orang (X5), dan Keputusan Pembelian (Y), menunjukkan bahwa hasil nilai $r$ hitung lebih besar dari $r$ Tabel, yaitu 0,1519 , yang berarti indikator masing-masing variabel yang digunakan dalam penelitian ini dinyatakan valid dan dapat digunakan sebagai alat ukur variabel.

\section{Reliabilitas}

Suatu kuesioner dikatakan reliabel atau handal jika jawaban pertanyaan adalah konsisten atau stabil dari waktu ke waktu (Ghozali, 2011).

Uji reliabilitas adalah tingkat kestabilan suatu alat pengukur dalam mengukur suatu gejala/kejadian. Semakin tinggi reliabilitas suatu alat pengukur, semakin stabil pula alat pengukur tersebut.

Dalam pengambilan keputusan reliabilitas, suatu instrumen dikatakan reliabel jika nilai Cronbach's Alpha lebih besar dari 0,6 (Malhotra, 2010).

Hasil uji reliabilitas yang dilaksanakan, pada Produk (X1), Harga (X2), Promosi (X.3), Tempat (X4), Orang (X5), dan Keputusan Pembelian (Y), menunjukkan bahwa hasil Cronbach's Alpha nya lebih besar dari 0,6, sehingga data tersebut dinyatakan reliable.

\section{ANALISIS DATA}

Data yang diperoleh dianalisis dengan menggunakan analisis deskriptif dan analisis inferensial. Analisis deskriptif digunakan untuk mengetahui gambaran responden yang menjadi subjek penelitian.

Langkah pertama dalam analisis inferensial yaitu Uji Asumsi Klasik yang terdiri dari uji normalitas, uji multikolinieritas, dan uji heteroskedastisitas. Selanjutnya digunakan analisis regresi linier berganda yang digunakan untuk mengetahui besarnya pengaruh langsung dan tidak langsung antar variabel yang digunakan dalam penelitian ini.

Pengujian hipotesis dengan Uji t (Parsial) digunakan untuk mengetahui pengaruh dari masing-masing variabel, baik variabel bebas terhadap variabel terikat tersebut yang signifikan secara statistik.

Uji F (simultan) untuk mengetahui pengaruh secara keseluruhan dari variabel bebas terhadap variabel terikat, apakah secara statistik, variabel bebas mempunyai pengaruh yang signifikan terhadap variabel terikat.

\section{HASIL DAN PEMBAHASAN}

Metode pengujian dengan menggunakan statistik deskriptif dan statistik inferensial, penulis ingin menguji pengaruh antara variabel bebas terhadap variabel terikat.

Dimana Hasil analisis deskriptif menunjukkan bahwa responden yang menjadi objek dalam penelitian ini terdiri dari laki-laki sebanyak 54 orang atau sebesar 32.3\%. Reponden yang berjenis kelamin perempuan sebanyak 113 orang atau sebesar 67.6\%. responden yang berusia kurang dari 20 tahun berjumlah 19 orang dengan persentase $11.3 \%$, 21-30 tahun sebanyak 75 orang dengan persentase $44.9 \%$. Responden yang berusia 3140 tahun sebanyak 53 orang dengan persentase $31.7 \%$. Responden yang berusia $41-50$ tahun sebanyak 18 orang dengan persentase $10.7 \%$. Dan responden dengan usia $>50$ tahun sebanyak 2 orang dengan persentase $0.01 \%$. responden yang berpendidikan SMP sebanyak 23 orang dengan persentase $13.7 \%$, SMA sebanyak 90 orang dengan persentase $53.8 \%$. Responden yang berpendidikan Sarjana sebanyak 28 orang dengan persentase $16.7 \%$. Responden yang berpendidikan Master sebanyak 1 orang dengan persentase $0.005 \%$. Dan sisanya sebanyak 25 orang dengan persentase $14.9 \%$. responden yang menjabat sebagai Pemilik sebanyak 23 orang dengan persentase $13.7 \%$, Manajer sebanyak 95 orang dengan persentase $56.8 \%$. Responden yang menjabat sebagai bagian pemesanan sebanyak 40 orang dengan persentase $23.9 \%$. Dan sisanya sebanyak 9 orang dengan persentase $0.05 \%$. responden yang telah berlangganan selama kurang dari 1 tahun sebanyak 37 orang dengan persentase $18.5 \%$, yang telah berlangganan lebih dari 1 tahun sampai 2 tahun sebanyak 32 orang dengan persentase $19.1 \%$. Responden yang yang telah berlangganan selama kurang dari 2 tahun sampai 5 tahun sebanyak 55 orang dengan persentase $32.9 \%$. Responden yang telah berlangganan selama kurang dari 5 sampai 7 tahun sebanyak 12 orang dengan persentase $7.1 \%$. Responden yang telah berlangganan selama kurang dari 7 sampai 10 tahun sebanyak 25 orang dengan persentase $14.9 \%$. Dan sisanya sebanyak 6 
orang dengan persentase $3.5 \%$. responden yang melakukan transaksi setiap hari, yang melakukan transaksi beberapa hari sekali sebanyak 25 orang dengan persentase $14.9 \%$. Responden yang melakukan transaksi satu kali dalam seminggu sebanyak 55 orang dengan persentase $32.9 \%$. Responden yang yang melakukan transaksi satu kali dalam 2 minggu sebanyak 29 orang dengan persentase $17.3 \%$. Responden yang melakukan transaksi sebulan sekali sebanyak 45 orang dengan persentase 26.9\%.Dan sisanya sebanyak 13 orang dengan persentase $7.7 \%$.

\section{Uji Asumsi Klasik}

\section{Uji Normalitas}

Uji statistik sederhana yang sering digunakan untuk menguji asumsi normalitas adalah dengan menggunakan uji normalitas dari Kolmogorov Smirnov. Metode pengujian normal tidaknya distribusi data dilakukan dengan melihat nilai signifikansi variabel, jika signifikan lebih besar dari alpha 5\% (0.05), maka menunjukkan distribusi data normal.

\section{Tabel 1. Uji Normalitas}

\section{Unstandardized}

Residual

\begin{tabular}{ll}
\hline $\begin{array}{l}\text { Kolmogorov- } \\
\text { Smirnov Z }\end{array}$ & 1.218 \\
\hline $\begin{array}{l}\text { Asymp. Sig. (2- } \\
\text { tailed) }\end{array}$ & 0.103 \\
\hline Sumber: Data yang diolah &
\end{tabular}

Sumber: Data yang diolah

Tabel diatas menunjukkan bahwa nilai signifikansi variabel yaitu sebesar 0.103 lebih besar dari alpha 0.05 , ini menunjukkan bahwa distribusi data dinyatakan normal.

\section{Uji Multikolinieritas}

Pengujian ada tidaknya gejala multikolinieritas dilakukan dengan memperhatikan nilai matriks kolerasi yang dihasilkan pada saat pengolahan data serta nilai VIF (Variance Inflation Factor) dan tolerance-nya.

Tabel 2. Uji Multikolinieritas

\begin{tabular}{ccc} 
Model & $\begin{array}{c}\text { Colinearity } \\
\text { Statistics }\end{array}$ & Keterangan \\
& Tolerance VIF & \\
\hline
\end{tabular}

\begin{tabular}{lccl}
\hline $\begin{array}{l}\text { Produk } \\
\left(\mathbf{X}_{1}\right)\end{array}$ & 0.317 & 3.153 & $\begin{array}{l}\text { Bebas } \\
\text { Multikolinieritas }\end{array}$ \\
\hline $\begin{array}{l}\text { Harga } \\
\left(\mathbf{X}_{2}\right)\end{array}$ & 0.220 & 4.541 & $\begin{array}{l}\text { Bebas } \\
\text { Multikolinieritas }\end{array}$ \\
\hline $\begin{array}{l}\text { Promosi } \\
\left(\mathbf{X}_{3}\right)\end{array}$ & 0.194 & 5.142 & $\begin{array}{l}\text { Bebas } \\
\text { Multikolinieritas }\end{array}$ \\
\hline $\begin{array}{l}\text { Tempat } \\
\left(\mathbf{X}_{4}\right)\end{array}$ & 0.505 & 1.980 & $\begin{array}{l}\text { Bebas } \\
\text { Multikolinieritas }\end{array}$ \\
\hline $\begin{array}{l}\text { Orang } \\
\left(\mathbf{X}_{5}\right)\end{array}$ & 0.319 & 3.136 & $\begin{array}{l}\text { Bebas } \\
\text { Multikolinieritas }\end{array}$ \\
\hline $\begin{array}{l}\text { Proses } \\
\left(\mathbf{X}_{6}\right)\end{array}$ & 0.400 & 2.499 & $\begin{array}{l}\text { Bebas } \\
\text { Multikolinieritas }\end{array}$ \\
\hline
\end{tabular}

Sumber: Data yang diolah

Berdasarkan tabel diatas dapat dilihat bahwa setiap variabel mempunyai nilai tolerance $>0.1$ dan nilai $\mathrm{VIF}<10$, sehingga dapat disimpulkan bahwa tidak terjadi multikolinieritas antara variabel bebas dalam model regresi ini.

\section{Uji Heteroskedastisitas}

Salah satu cara untuk melihat ada tidaknya heteroskedastisitas adalah menggunakan uji Glejser. Uji ini dilakukan dengan cara melakukan regersi variabel bebas dengan nilai absolut dari residualnya.

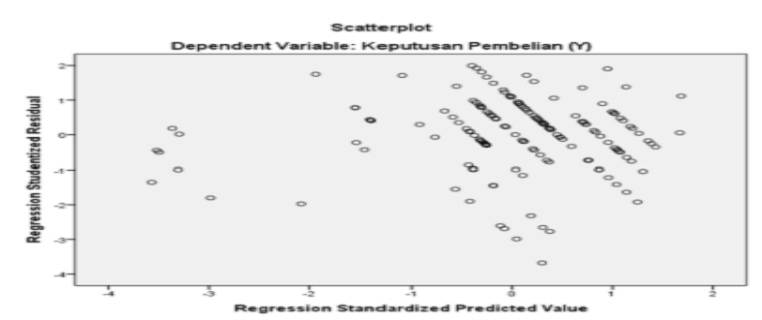

Gambar Hasil Uji Heteroskedastisitas

Berdasarkan tabel di atas dapat dilihat bahwa hasil uji heteroskedastisitas dapat di deteksi dengan melihat ada tidaknya pola tertentu pada grafik scatter plot, hal tersebut menunjukkan bahwa tidak terdapat pola tertentu, serta titik titik menyebar di atas dan dibawah angka 0 pada sumbu Y sehingga dapat diartikan bahwa model regresi tidak memiliki gejala adanya heteroskedastisitas, atau terdapat kesamaan varians dari residual satu pengamatan ke pengamatan lain. Pada Grafik Scatterplot yang disajikan, terlihat titik-titik menyebar secara acak tidak membentuk sebuah pola tertentu yang jelas serta tersebar baik di atas maupun di bawah angka nol pada sumbu Y. Hal ini berarti tidak terjadi Heteroskedastisitas (terjadi 
Sylvia \& Nur Rahmah, pengaruh bauran pemasaran (marketing mix) terhadap keputusan pembelian ....

Homokedastisitas) pada model regresi sehingga model regresi layak digunakan untuk memprediksi keputusan pembelian berdasarkan masukan dari variabel independennya yaitu produk (X1), harga (X2), promosi (X3), tempat (X4), orang (X5), dan proses (X6).

\section{Analisis Regresi Linier Berganda}

Analisis regresi linier berganda digunakan untuk mengetahui kekuatan hubungan dari variabel independen terhadap variabel dependen yaitu pengaruh bauran pemasaran berupa variabel produk (X1), harga (X2), promosi (X3), tempat (X4), orang (X5), dan proses (X6) terhadap Keputusan pembelian di PT. EPM Batam.

Hasil pengolahan data dengan menggunakan program SPSS selengkapnya akan dijelaskan pada Tabel berikut ini:

\section{Tabel 3. Hasil Analisis Regresi Linier Berganda}

\begin{tabular}{|c|c|c|c|c|c|}
\hline $\begin{array}{c}\begin{array}{c}\text { Depen } \\
\text { den } \\
(\mathbf{Y})\end{array} \\
\end{array}$ & $\begin{array}{l}\text { Indepen } \\
\text { den }(X)\end{array}$ & B & $\mathbf{T}$ & Sig & Pengaruh \\
\hline \multirow{7}{*}{$\begin{array}{c}\text { Keput } \\
\text { usan } \\
\text { Pembe } \\
\text { lian }\end{array}$} & Produk & 0.168 & 2.517 & 0.013 & $\begin{array}{l}\text { Positif dan } \\
\text { Signifikan }\end{array}$ \\
\hline & Harga & 0.231 & 3.335 & 0.001 & $\begin{array}{l}\text { Positif dan } \\
\text { Signifikan }\end{array}$ \\
\hline & Promosi & 0.348 & 4.407 & 0.000 & $\begin{array}{c}\text { Positif dan } \\
\text { Signifikan }\end{array}$ \\
\hline & Tempat & 0.028 & 0.645 & 0.520 & $\begin{array}{c}\text { Positif tidak } \\
\text { Signifikan }\end{array}$ \\
\hline & Orang & 0,263 & 4.175 & 0.000 & $\begin{array}{l}\text { Positif dan } \\
\text { Signifikan }\end{array}$ \\
\hline & Proses & 0.138 & 2.228 & 0.027 & $\begin{array}{l}\text { Positif dan } \\
\text { Signifikan }\end{array}$ \\
\hline & $\begin{array}{c}\text { (Consta } \\
\text { nt) }\end{array}$ & 0.795 & 0.899 & 0.370 & \\
\hline \multicolumn{2}{|l|}{ F hitung } & \multicolumn{4}{|c|}{$=149,622$} \\
\hline \multicolumn{2}{|l|}{ t tabel } & \multicolumn{4}{|l|}{$=1,97$} \\
\hline \multicolumn{2}{|l|}{ F tabel } & \multicolumn{4}{|l|}{$=2,16$} \\
\hline \multicolumn{2}{|l|}{$\mathrm{R}$} & \multicolumn{4}{|c|}{$=0,921$} \\
\hline \multicolumn{2}{|c|}{ R Square } & \multicolumn{4}{|c|}{$=0,849$} \\
\hline \multicolumn{2}{|c|}{ Adjusted R. Square } & \multicolumn{4}{|c|}{$=0.843$} \\
\hline
\end{tabular}

Sumber: Data yang diolah

Adapun bentuk model persamaan regresi yang dapat dituliskan dari tabel tabels dalam persamaan sebagai berikut:

$$
\begin{gathered}
Y=0.795+0.168 X_{1}+0.231 X_{2}+0.348 \\
X_{3}+0.028 X_{4}+0.263 X_{5}+0.138 X_{6}
\end{gathered}
$$

\section{Model Persamaan Regresi Linier Berganda}

1. Constanta memiliki nilai sebesar 0,795 yang berarti jika variabel Produk, Harga, Promosi, Tempat, Orang, dan Proses bernilai 0, maka variabel Kepuasan pelanggan memiliki nilai sebesar 0,795 .

2 Koefiensi regresi variabel Produk $\left(\mathrm{X}_{1}\right)$ adalah sebesar 0.168 , artinya jika variabel independen lain nilainya tetap dan nilai dari Produk mengalami kenaikan 1, maka nilai dari Keputusan Pembelian akan mengalami kenaikan sebesar 0.168 . Begitupula sebaliknya, jika variabel independen lain nilainya tetap dan nilai dari Produk mengalami penurunan 1, maka nilai dari variabel Keputusan Pembelian akan mengalami penurunan sebesar 0.168 .

3 Koefiensi regresi variabel Harga $\left(\mathrm{X}_{2}\right)$ adalah sebesar 0.231 , artinya jika variabel independen lain nilainya tetap dan nilai dari Harga mengalami kenaikan 1, maka nilai dari Keputusan Pembelian akan mengalami kenaikan sebesar 0.231. Begitupula sebaliknya, jika variabel independen lain nilainya tetap dan nilai dari Harga mengalami penurunan 1, maka nilai dari variabel Keputusan Pembelian akan mengalami penurunan sebesar 0.231 .

4 Koefiensi regresi variabel Promosi $\left(\mathrm{X}_{3}\right)$ adalah sebesar 0.348 , artinya jika variabel independen lain nilainya tetap dan nilai dari Promosi mengalami kenaikan 1, maka nilai dari Keputusan Pembelian akan mengalami kenaikan sebesar 0.348. Begitupula sebaliknya, jika variabel independen lain nilainya tetap dan nilai 
dari Promosi mengalami penurunan 1, maka nilai dari variabel Keputusan Pembelian akan mengalami penurunan sebesar 0.348 .

5 Koefiensi regresi variabel Tempat $\left(\mathrm{X}_{4}\right)$ adalah sebesar 0.028 , artinya jika variabel independen lain nilainya tetap dan nilai dari Tempat mengalami kenaikan 1, maka nilai dari Keputusan Pembelian akan mengalami kenaikan sebesar 0.028 . Begitupula sebaliknya, jika variabel independen lain nilainya tetap dan nilai dari Tempat mengalami penurunan 1, maka nilai dari variabel Keputusan Pembelian akan mengalami penurunan sebesar 0.028 .

6 Koefiensi regresi variabel Orang $\left(X_{5}\right)$ adalah sebesar 0.263 , artinya jika variabel independen lain nilainya tetap dan nilai dari Orang mengalami kenaikan 1, maka nilai dari Keputusan Pembelian akan mengalami kenaikan sebesar 0.263. Begitupula sebaliknya, jika variabel independen lain nilainya tetap dan nilai dari Orang mengalami penurunan 1, maka nilai dari variabel Keputusan Pembelian akan mengalami penurunan sebesar 0.263 .

7 Koefiensi regresi variabel Proses $\left(\mathrm{X}_{6}\right)$ adalah sebesar 0.138 , artinya jika variabel independen lain nilainya tetap dan nilai dari Proses mengalami kenaikan 1, maka nilai dari Keputusan Pembelian akan mengalami kenaikan sebesar 0.138. Begitupula sebaliknya, jika variabel independen lain nilainya tetap dan nilai dari Proses mengalami penurunan 1, maka nilai dari variabel Keputusan Pembelian akan mengalami penurunan sebesar 0.138 .

\section{Pengujian Hipotesis \\ Uji t (Parsial)}

Uji statistik $\mathrm{t}$ dilakukan untuk mengetahui pengaruh masing-masing variabel terhadap variabel dependen secara parsial. Pengujian $t$ yang dilakukan menggunakan nilai $\alpha$ (alpha) sebesar 5\%. Dengan demikian perhitungan uji t dapat dilihat melalui tabel yang memiliki alpha 5\% atau 0.05 dan nilai derajat kebebasan (df) yang akan digunakan. Pengujian $t$ ini memiliki ketentuan sebagai berikut: a. $\quad$ Jika $t_{\text {hitung }}>t_{\text {tabel }}$ dan nilai signifikansi $<$ 0.05 maka Ho ditolak dan Ha diterima, jadi variabel independen (X) berpengaruh signifikan terhadap variabel dependen $(\mathrm{Y})$

b. Jika $t_{\text {hitung }}<\mathrm{t}_{\text {tabel }}$ dan nilai signifikansi $>$ 0.05 maka Ho diterima dan Ha ditolak, jadi veriabel indenpenden $(X)$ tidak berpengaruh signifikan terhadap variabel dependen $(\mathrm{Y})$.

Penelitian ini menggunakan signifikansi 0.05 dengan derajat kebebasan $(\mathrm{df})=\mathrm{n}-2$ dengan perhitungan bahwa jumlah responden (n) sebesar 167 maka nilai $\mathrm{df}=167-2$ yaitu 165. Maka dapat dilihat pada tabel statistik pada nilai signifikansi 0.05 dengan nilai df sebesar 165 diperoleh $t_{\text {tabel }}$ sebesar 1,97.

Tabel 4. Hasil uji t

\begin{tabular}{|c|c|c|c|c|}
\hline $\begin{array}{l}\text { Variabel } \\
\text { Dependen }\end{array}$ & $\begin{array}{c}\text { Variabel } \\
\text { Indenpen } \\
\text { den }\end{array}$ & B & $\mathbf{T}$ & Sig. \\
\hline \multirow{7}{*}{$\begin{array}{l}\text { Keputusan } \\
\text { Pembelian } \\
\text { Pelanggan } \\
\text { (Y) }\end{array}$} & (Constant) & .795 & .899 & .370 \\
\hline & $\begin{array}{l}\text { Produk } \\
\left(\mathrm{X}_{1}\right)\end{array}$ & .168 & 2.517 & .013 \\
\hline & Harga $\left(X_{2}\right)$ & .231 & 3.335 & .001 \\
\hline & $\begin{array}{l}\text { Promosi } \\
\left(\mathrm{X}_{3}\right)\end{array}$ & .348 & 4.407 & .000 \\
\hline & $\begin{array}{l}\text { Tempat } \\
\left(\mathrm{X}_{4}\right)\end{array}$ & .028 & .645 & .520 \\
\hline & $\begin{array}{l}\text { Orang } \\
\left(X_{5}\right)\end{array}$ & .263 & 4.175 & .000 \\
\hline & $\begin{array}{l}\text { Proses } \\
\left(\mathrm{X}_{6}\right)\end{array}$ & .138 & 2.228 & .027 \\
\hline
\end{tabular}

Sumber: Data yang diolah

\section{Uji F (Simultan)}

Uji $F$ ini bertujuan untuk menguji apakah terdapat pengaruh secara bersama-sama (simultan) dari masing-masing variabel independen terhadap variabel dependen. 
Tabel 5. Hasil uji F

\begin{tabular}{|r|r|r|r|c|c|}
\hline Model & $\begin{array}{c}\text { Sum of } \\
\text { Squares }\end{array}$ & df & $\begin{array}{c}\text { Mean } \\
\text { Square }\end{array}$ & $\mathrm{F}$ & Sig. \\
\hline $\begin{array}{r}\text { Regre } \\
\text { ssion }\end{array}$ & 962,453 & 6 & 160,409 & 149,622 &, 00 \\
$1 \begin{array}{l}\text { Resid } \\
\text { ual } \\
\text { Total }\end{array}$ & 171,535 & 160 & 1,072 & & $0^{\mathrm{b}}$ \\
\hline
\end{tabular}

a. Dependent Variabel: Keputusan Pembelian ( $Y$ )

b. Predictors: (Constant), Proses (X6), Tempat (X4),

Produk (X1), Orang (X5), Harga (X2), Promosi (X3)

\section{a. Hipotesis 1}

Berdasarkan Hipotesis 1 ada pengaruh positif dan signifikan antara variable $\mathrm{X}_{1}$ terhadap keputusan pembelian (Y). Hipotesis ini di dukung apabila nilai probabilitas signifikansi menunjukkan nilai $<0,05$. Berdasarkan tabel di atas dapat dilihat bahwa variabel Produk $\left(X_{I}\right)$ di peroleh $t_{\text {hitung }}$ sebesar 2.517 dengan signifikansi sebesar 0,013 (sig. < 0,05). Hasil penelitian tersebut menunjukkan angka signifikansi jauh lebih kecil dari 0,05 dan thitung sebesar $2.517>t_{\text {tabel }}$ sebesar 1,97, maka model regresi dapat digunakan untuk memprediksi variabel dependen, atau dengan kata lain variabel produk $\left(X_{1}\right)$ berpengaruh secara positif dan signifikan terhadap variabel keputusan pembelian (Y). Berdasarkan analisis tersebut maka disimpulkan hipotesis 1 dalam penelitian ini diterima.

\section{b. Hipotesis 2}

Berdasarkan Hipotesis 2 ada pengaruh positif dan signifikan antara variable $\mathrm{X}_{2}$ terhadap keputusan pembelian (Y). Hipotesis ini di dukung apabila nilai probabilitas signifikansi menunjukkan nilai $<0,05$. Berdasarkan tabel di atas dapat dilihat bahwa variabel Harga $\left(X_{2}\right)$ di peroleh $t_{\text {hitung }}$ sebesar 3.335 dengan signifikansi sebesar 0,001 (sig. < 0,05). Hasil penelitian tersebut menunjukkan angka signifikansi jauh lebih kecil dari 0,05 dan $t_{\text {hitung }}$ sebesar $3.335>$ $t_{\text {tabel }}$ sebesar 1,97, maka model regresi dapat digunakan untuk memprediksi variabel dependen, atau dengan kata lain variabel Harga $\left(X_{2}\right)$ berpengaruh secara positif dan signifikan terhadap variabel keputusan pembelian (Y). Berdasarkan analisis tersebut maka disimpulkan hipotesis 2 dalam penelitian ini diterima.

\section{c. Hipotesis 3}

Berdasarkan Hipotesis 3 ada pengaruh positif dan signifikan antara variable $\mathrm{X}_{3}$ terhadap keputusan pembelian (Y). Hipotesis ini di dukung apabila nilai probabilitas signifikansi menunjukkan nilai $<0,05$. Berdasarkan tabel di atas dapat dilihat bahwa variabel Promosi $\left(X_{3}\right)$ di peroleh thitung sebesar 4.407 dengan signifikansi sebesar 0,000 (sig. < 0,05). Hasil penelitian tersebut menunjukkan angka signifikansi jauh lebih kecil dari 0,05 dan thitung sebesar $4.407>t_{\text {tabel }}$ sebesar 1,97, maka model regresi dapat digunakan untuk memprediksi variabel dependen, atau dengan kata lain variabel Harga $\left(X_{3}\right)$ berpengaruh secara positif dan signifikan terhadap variabel keputusan pembelian (Y). Berdasarkan analisis tersebut maka disimpulkan hipotesis 3 dalam penelitian ini diterima.

\section{d. Hipotesis 4}

Berdasarkan Hipotesis 4 ada pengaruh positif dan signifikan antara variable $\mathrm{X}_{4}$ terhadap keputusan pembelian (Y). Hipotesis ini di dukung apabila nilai probabilitas signifikansi menunjukkan nilai $<0,05$. Berdasarkan tabel di atas dapat dilihat bahwa variabel Tempat $\left(X_{4}\right)$ di peroleh thitung sebesar 0,645 dengan signifikansi sebesar 0,520 (sig. < 0,05). Hasil penelitian tersebut menunjukkan angka signifikansi jauh lebih besar dari 0,05 dan thitung sebesar $0.645>\mathrm{t}_{\text {tabel }}$ sebesar 1,97, maka model regresi dapat digunakan untuk memprediksi variabel dependen, atau dengan kata lain variabel Tempat $\left(X_{4}\right)$ tidak berpengaruh secara positif dan signifikan terhadap variabel keputusan pembelian (Y). Berdasarkan analisis tersebut maka disimpulkan hipotesis 4 dalam penelitian ini ditolak.

\section{e. Hipotesis 5}

Berdasarkan Hipotesis 5 ada pengaruh positif dan signifikan antara variable $\mathrm{X}_{5}$ terhadap keputusan pembelian (Y). Hipotesis ini di dukung apabila nilai probabilitas signifikansi menunjukkan nilai $<0,05$. Berdasarkan tabel di atas dapat dilihat bahwa variabel Orang $\left(X_{5}\right)$ di 
peroleh $t_{\text {hitung }}$ sebesar 4,175 dengan signifikansi sebesar 0,000 (sig. < 0,05). Hasil penelitian tersebut menunjukkan angka signifikansi jauh lebih kecil dari 0,05 dan $t_{\text {hitung }}$ sebesar 4,175 > $\mathrm{t}_{\text {tabel }}$ sebesar 1,97, maka model regresi dapat digunakan untuk memprediksi variabel dependen, atau dengan kata lain variabel Orang $\left(X_{5}\right)$ berpengaruh secara positif dan signifikan terhadap variabel keputusan pembelian (Y). Berdasarkan analisis tersebut maka disimpulkan hipotesis 5 dalam penelitian ini diterima.

\section{f. Hipotesis 6}

Berdasarkan Hipotesis 6 ada pengaruh positif dan signifikan antara variable $\mathrm{X}_{6}$ terhadap keputusan pembelian (Y). Hipotesis ini di dukung apabila nilai probabilitas signifikansi menunjukkan nilai $<0,05$. Berdasarkan tabel di atas dapat dilihat bahwa variabel Proses $\left(X_{6}\right)$ di peroleh $t_{\text {hitung }}$ sebesar 2,228 dengan signifikansi sebesar 0,027 (sig. < 0,05). Hasil penelitian tersebut menunjukkan angka signifikansi jauh lebih kecil dari 0,05 dan $t_{\text {hitung }}$ sebesar 2,228 > $\mathrm{t}_{\text {tabel }}$ sebesar 1,97, maka model regresi dapat digunakan untuk memprediksi variabel dependen, atau dengan kata lain variabel Proses $\left(X_{6}\right)$ berpengaruh secara positif dan signifikan terhadap variabel keputusan pembelian (Y). Berdasarkan analisis tersebut maka disimpulkan hipotesis 6 dalam penelitian ini diterima.

\section{g. Hipotesis 7}

Hipotesis 7 menyatakan berdasarkan hasil Uji Anova atau Uji Statistik F dapat diketahui bahwa secara bersama-sama (simultan) variabel independen memeiliki pengaruh yang signifikan terhadap variabel dependen. Hal ini terbukti dengan $\mathrm{F}_{\text {hitung }} 149.622>\mathrm{F}_{\text {tabel }} 2,16$ dengan nilai signifikansi sebesar $0,000<0,05$ karena nilai signifikansi lebih kecil dari 0,05 maka model regresi dapat digunakan untuk memprediksi Keputusan pembelian atau dapat dikatakan variabel Bauran Pemasaran yang terdiri dari produk (X1), harga $(\mathrm{X} 2)$, promosi (X3), tempat (X4), orang (X5), dan proses (X6) secara bersama-sama berpengaruh terhadap Keputusan pembelian (Y). Berdasarkan Hipotesis 7 maka variabel Bauran Pemasaran berpengaruh secara simultan terbukti dan dapat diterima.

\section{PEMBAHASAN PENELITIAN}

Penelitian ini bertujuan untuk menguji dan menganalisis bagaimana pengaruh antara variabel independen, yaitu produk (X1), harga (X2), promosi (X3), tempat (X4), orang (X5), dan proses (X6) pembelian pada PT. EPM Batam. Populasi dalam penelitian ini adalah pelanggan atau Costumer PT. EPM Batam.

\section{Pengaruh Produk $\left(\mathbf{X}_{1}\right) \quad$ Terhadap Keputusan pembelian (Y)}

Faktor ini memiliki 5 item pertanyaan. Dilihat dari tabel hasil uji konstanta dan koefisien regresi diketahui bahwa setiap kenaikan 1 poin dari faktor Produk $\left(\mathrm{X}_{1}\right)$ mengakibatkan kepuasan pelanggan (Y) mengalami peningkatan sebesar 0,168 atau $16,8 \%$. Dari hasil uji t untuk variabel yang sama adalah memiliki nilai signifikan 0,013 dimana nilai tersebut lebih kecil dari 0,05 sehingga mempunyai pengaruh positif dan signifikan terhadap keputusan pembelian pada produk Kara Santan di PT EPM.

Dalam penelitian ini Produk $\left(\mathrm{X}_{1}\right)$ sangat diperhatikan karena meskipun produk Kara Santan merupakan produk yang cukup diminati dan lebih banyak dicari bila dibandingkan dengan produk lainnya, tetap saja tidak bisa menghindari fakta bilamana suatu hari akan muncul produk yang lebih bagus dan berkualitas, dan karena beberapa pelanggan memberikan respon kurang baik maka variabel Produk harus lebih ditingkatkan agar lebih baik lagi.

Hasil ini selaras dengan penelitian yang berjudul Pengaruh Produk, Harga, Saluran Distribusi, dan Promosi Terhadap Keputusan Pembelian Mobil Avanza oleh Danny Tri Bagus Irawan dan Budhi Satrio (2015) "Produk memiliki pengaruh positif dan signifikan terhadap keputusan pembel0069an. Semakin baik produk yang dimiliki Toyota Avanza tersebut akan semakin meningkatkan keputusan konsumen dalam membeli.

\section{Pengaruh Harga $\left(X_{2}\right)$ Terhadap Keputusan pembelian (Y)}

Faktor ini memiliki 5 item pertanyaan. Dilihat dari tabel hasil uji konstanta dan koefisien regresi diketahui bahwa setiap kenaikan 1 poin dari faktor Harga $\left(\mathrm{X}_{2}\right)$ mengakibatkan kepuasan pelanggan (Y) mengalami 
peningkatan sebesar 0,231 atau $23,1 \%$. Dari hasil uji t untuk variabel yang sama adalah memiliki nilai signifikan 0,001 dimana nilai tersebut lebih kecil dari 0,05 sehingga mempunyai pengaruh positif dan signifikan terhadap keputusan pembelian pada produk Kara Santan di PT EPM.

Dalam penelitian Harga $\left(\mathrm{X}_{2}\right)$ harus diperhatikan karena walaupun pelanggan tetap setia membeli Kara Santan meskipun harganya dapat dikatakan lebih mahal dari beberapa merk saingannya, tetap saja tidak bisa menghindari fakta bilamana suatu hari akan muncul produk yang lebih murah dan berkualitas, dan karena beberapa pelanggan memberikan respon kurang baik maka variabel Harga harus lebih ditingkatkan agar lebih baik lagi.

Hasil ini selaras dengan penelitian yang berjudul Bauran Pemasaran (Marketing Mix) Pengaruhnya Terhadap Loyalitas Pelanggan Pada Fresh Mart Bahu Mall Manado oleh Christian A.D. Selang (2013), harga berpengaruh terhadap Loyalitas Konsumen, bahwa perusahaan mengadakan pendekatan terhadap penentuan harga berdasarkan tujuan yang hendak dicapainya. Adapun tujuan tersebut dapat berupa meningkatkan penjualan, mempertahankan market share, mempertahankan stabilitas harga, mencapai laba maksimum dan sebagainya.

\section{Pengaruh Promosi $\left(\mathbf{X}_{3}\right) \quad$ Terhadap Keputusan pembelian (Y)}

Faktor ini memiliki 5 item pertanyaan. Dilihat dari tabel hasil uji konstanta dan koefisien regresi diketahui bahwa setiap kenaikan 1 poin dari faktor Promosi $\left(\mathrm{X}_{3}\right)$ mengakibatkan keputusan pelanggan (Y) mengalami peningkatan sebesar 0,348 atau 34,8\%. Dari hasil uji t untuk variabel yang sama adalah memiliki nilai signifikan 0,000 dimana nilai tersebut lebih kecil dari 0,05 sehingga mempunyai pengaruh positif dan signifikan terhadap keputusan pembelian pada produk Kara Santan di PT EPM.

Dalam penelitian Promosi $\left(\mathrm{X}_{3}\right)$ sangat diperhatikan karena peran dari Promosi $\left(\mathrm{X}_{3}\right)$ juga begitu diperlukan untuk dapat lebih meningkatkan keputusan pembelian pelanggan. Peningkatan Promosi $\left(\mathrm{X}_{3}\right)$ dalam pernyataan Produk Kara lebih banyak dicari oleh pelanggan di banding dengan merk lainnya menunjukkan bahwa promosi yang dilakukan untuk produk Kara Santan sangat membantu dalam keputusan pembelian pelanggan.

Hasil ini selaras dengan penelitian yang berjudul Analisa Marketing Mix 7P (Product, Place, Promotion, Price, Partisipant, Process, dan Physical Evidence) Terhadap Keputusan Pembelian Produk Klinik Kecantikan Teta di Surabaya oleh Hendri Sukotjo dan Radix Sumanto (2010). Variabel promosi adalah variabel yang paling dominan terhadap keputusan pembelian pada klinik kecantikan Teta di kota Surabaya, aspek ini erat kaitannya dalam hal promosi yang bersifat edukatif dan persuasif seperti yang telah dilakukan dalam bentuk advetorial di media cetak, talk show informatif pada media elektronik radio dan penyelenggaraan member get member, voucher pembelian serta promo pada media luar ruang yang memuat promo/event bulanan yang sangat efektif mempengaruhi keputusan pembelian.

\section{Pengaruh Tempat $\left(\mathbf{X}_{4}\right)$ Terhadap Keputusan pembelian (Y)}

Faktor ini memiliki 5 item pertanyaan. Dilihat dari tabel hasil uji konstanta dan koefisien regresi diketahui bahwa setiap kenaikan 1 poin dari faktor Tempat $\left(\mathrm{X}_{4}\right)$ mengakibatkan keputusan pembelian pelanggan (Y) mengalami peningkatan sebesar 0,028 atau $2,8 \%$. Dari hasil uji t untuk variabel yang sama adalah memiliki nilai signifikan 0,520 dimana nilai tersebut lebih besar dari 0,05 sehingga mempunyai pengaruh yang tidak signifikan keputusan pembelian pada produk Kara Santan di PT EPM.

Dalam penelitian ini Tempat $\left(\mathrm{X}_{4}\right)$ juga sangat diperlukan, meskipun tidak semua pelanggan mengunjungi perusahaan untuk mengambil pesanan dan menggunakan fasilitas kantor untuk melakukan kerjasama, tapi tetap saja aspek tempat menjadi aspek yang penting bagi keputusan pembelian pelanggan.

Hasil ini selaras dengan penelitian yang berjudul Pengaruh Produk, Harga, Promosi, dan Distribusi Terhadap Keputusan Pembelian Pelanggan Pada Produk Projector Microvision oleh Doni Hariadi \& Soebari Martoadmodjo (2012) mengatakan bahwa lokasi atau tempat keberadaan PT Smart Vision Surabaya menjadi perhitungan bagi konsumen untuk mengunjungi perusahaan tersebut atau tidak. 
Pelanggan atau calon konsumen akan memperhitungkan jauh-dekat serta mudah tidaknya lokasi itu dicapai.

\section{Pengaruh Orang $\left(\mathbf{X}_{5}\right) \quad$ Terhadap Keputusan pembelian (Y)}

Faktor ini memiliki 5 item pertanyaan. Dilihat dari tabel hasil uji konstanta dan koefisien regresi diketahui bahwa setiap kenaikan 1 poin dari Orang $\left(\mathrm{X}_{5}\right)$ mengakibatkan keputusan pembelian pelanggan (Y) mengalami peningkatan sebesar 0,263 atau 26,3\%. Dari hasil uji t untuk variabel yang sama adalah memiliki nilai signifikan 0,000 dimana nilai tersebut lebih kecil dari 0,05 sehingga mempunyai pengaruh positif dan signifikan terhadap keputusan pembelian pada produk Kara Santan di PT EPM.

Dalam penelitian ini Orang $\left(\mathrm{X}_{5}\right)$ juga begitu diperlukan, untuk dapat meningkatkan keputusan pembelian pelanggan melalui variabel Orang $\left(\mathrm{X}_{5}\right)$ hal ini dapat disebabkan oleh pernyataan Pelayanan PT EPM memuaskan yang dapat diartikan sebagai variabel Orang sudah sangat membantu dalam peningkatan keputusan pembelian pelanggan.

Hasil ini selaras dengan penelitian yang berjudul Analisa Marketing Mix 7P (Product, Place, Promotion, Price, Partisipant, Process, dan Physical Evidence) Terhadap Keputusan Pembelian Produk Klinik Kecantikan Teta di Surabaya oleh Hendri Sukotjo dan Radix Sumanto (2010), orang berpengaruh positif dan signifikan terhadap keputusan pembelian produk Klinik Kecantikan.

\section{Pengaruh Proses $\left(\mathbf{X}_{6}\right)$ Terhadap Keputusan pembelian (Y)}

Faktor ini memiliki 5 item pertanyaan. Dilihat dari tabel hasil uji konstanta dan koefisien regresi diketahui bahwa setiap kenaikan 1 poin dari Orang $\left(\mathrm{X}_{5}\right)$ mengakibatkan keputusan pembelian pelanggan (Y) mengalami peningkatan sebesar 0,138 atau $13,8 \%$. Dari hasil uji t untuk variabel yang sama adalah memiliki nilai signifikan 0,027 dimana nilai tersebut lebih kecil dari 0,05 sehingga mempunyai pengaruh positif dan signifikan terhadap keputusan pembelian pada produk Kara Santan di PT EPM.

Dalam penelitian ini Proses $\left(\mathrm{X}_{6}\right)$ juga begitu diperlukan, untuk dapat meningkatkan keputusan pembelian pelanggan melalui variabel Proses $\left(\mathrm{X}_{6}\right)$ hal ini dapat disebabkan oleh pernyataan Proses pembayaran mudah yang dapat diartikan sebagai variabel Proses terutama dalam bidang pelunasan tagihan pelanggan sudah sangat membantu dalam peningkatan keputusan pembelian pelanggan.

Hasil ini selaras dengan penelitian yang berjudul Analisa Marketing Mix 7P (Product, Place, Promotion, Price, Partisipant, Process, dan Physical Evidence) Terhadap Keputusan Pembelian Produk Klinik Kecantikan Teta di Surabaya oleh Hendri Sukotjo dan Radix Sumanto (2010), proses berpengaruh positif dan signifikan terhadap keputusan pembelian produk Klinik Kecantikan.

\section{Pengaruh Produk (X1), Harga (X2), Promosi (X3), Tempat (X4), Orang (X5), dan Proses (X6) terhadap Keputusan pembelian (Y)}

Faktor ini memiliki 6 item pertanyaan. Dilihat berdasarkan hasil analisis regresi berganda bahwa Pengaruh Produk, Harga, Promosi, Tempat, Orang dan Proses secara simultan berpengaruh terhadap Keputusan Pembelian Pelanggan (Y). Hasil tersebut diperoleh dari nilai $F_{\text {hitung }}>F_{\text {tabel }}(149.622>2,16)$. Berdasarkan kriteria tersebut maka H6 diterima, artinya pada $\mathrm{H}_{6}$ di buktikan bahwa Pengaruh Produk, Harga, Promosi, Tempat, Orang dan Proses secara simultan berpengaruh terhadap Keputusan Pembelian Pelanggan (Y). Hasil ini selaras dengan penelitian yang secara simultan menunjukkan pengaruh variabel bauran pemasaran yang terdiri dari produk, harga, promosi dan tempat secara bersamasama berpengaruh signifikan terhadap Proyektor Microvision pada PT. Smart Vision Surabaya. Hasil ini mengidikasikan bahwa naik turunnya terhadap keputusan pembelian konsumen ditentukan oleh seberapa baik kualitas produk, strategi harga yang ditawarkan, pelaksanaan promosi yang dilaksanakan perusahaan, serta keberadaan tempat perusahaan tersebut (Hariadi \& Martoadmodjo, 2012).

\section{PENUTUP \\ Kesimpulan}

Berdasarkan hasil penelitian dan pembahasan di atas, dapat ditarik kesimpulan bahwa secara parsial, 
Sylvia \& Nur Rahmah, pengaruh bauran pemasaran (marketing mix) terhadap keputusan pembelian ....

1. Produk berpengaruh positif dan signifikan terhadap keputusan pembelian.

2. Harga berpengaruh positif dan signifikan terhadap keputusan pembelian.

3. Promosi berpengaruh positif dan signifikan terhadap keputusan pembelian.

4. Tempat berpengaruh tidak signifikan terhadap keputusan pembelian.

5. Orang berpengaruh positif dan signifikan terhadap keputusan pembelian.

6. Proses berpengaruh positif dan signifikan terhadap keputusan pembelian.

Untuk kesimpulan secara bersama-sama (simultan), antara produk, harga, promosi, tempat, orang, dan proses berpengaruh signifikan terhadap keputusan pembelian.

\section{Saran}

Berdasarkan pada hasil dan pemaparan yang telah diuraikan, maka disarankan beberapa hal sebagai berikut:

1. Pada variabel Produk, PT. EPM harus meningkatkan ketentuan jaminan pengembalian produk untuk kondisikondisi tertentu untuk meningkatkan keputusan pembelian oleh pelanggan PT. EPM.

2. Pada variabel Harga, PT. EPM harus meningkatkan variasi sistem pembayaran untuk meningkatkan keputusan pembelian oleh pelanggan PT. EPM.

3. Pada variabel Promosi, PT. EPM harus mengubah sistem pemberian diskon dalam kondisi tertentu, seperti memberikan diskon lebih untuk pengambilan lebih banyak atau yang lainnya untuk meningkatkan keputusan pembelian oleh pelanggan PT. EPM.

4. Pada variabel Tempat, PT. EPM harus membuat inovasi dan terobosan baru untuk meningkatkan keputusan pembelian oleh pelanggan PT. EPM.

5. Pada variabel Orang, PT. EPM harus memberikan perhatian lebih terhadap kinerja dan pelatihan untuk Customer Service dalam menanggapi keluhan agar pelanggan merasa puas dan untuk meningkatkan keputusan pembelian oleh pelanggan PT. EPM.

6. Pada variabel Proses, PT. EPM harus memberikan perhatian lebih terhadap kinerja dan pelatihan untuk Customer Service dalam menanggapi keluhan agar pelanggan merasa puas dan untuk meningkatkan keputusan pembelian oleh pelanggan PT. EPM.

\section{DAFTAR PUSTAKA}

Bakara, Frisca Oktoviani. (2013). The Influence Of Television Advertising On Purchasing Decision Of Teenagers. Jurnal University of Sam Ratulangi. Manado.

Chattopadhyay, T., Shivani, S., \& Krishnan, M. (2010). Marketing Mix Elements Influencing Brand Equity and Brand Choice. VIKALPA, Vol 35 No. 3,pp:67-84.

Dharmmesta, B. S., \& Handoko, H. (2012). Manajemen Pemasaran Analisis Perilaku Pelanggan. Edisi Pertama. Yogyakarta: BPFE.

Ghozali, Imam. (2011). Aplikasi Analisis Multivariate dengan Program SPSS. Semarang: Badan Penerbit Universitas Diponegoro.

Hariadi, D., \& Martoadmodjo, S. (2012). Pengaruh Produk, Harga, Promosi, dan Distribusi Terhadap Keputusan Pembelian Pelanggan Pada Produk Projector Microvision. Jurnal Imu \& Riset Manajemen, Sekolah Tinggi Ilmu Ekonomi Indonesia. Surabaya. Vol 1 No. 8, pp:1-21.

Irawan, D. T., \& Satrio, B. (2015). Pengaruh Produk, Harga, Saluran Distribusi, dan Promosi Terhadap Keputusan Pembelian Mobil Avanza. Jurnal Imu dan Riset Manajemen, Sekolah Tinggi Ilmu Ekonomi Indonesia (STIESIA). Surabaya. Vol 4 No. 9, pp:1-18.

Kotler, \& Armstrong Garry (2008). Prinsipprinsip Pemasaran. Jilid 1. Jakarta: Erlangga. 
Kotler, \& Keller (2009). Manajemen Pemasaran. Jilid 1. Edisi 12. Jakarta: PT Indeks

Malhotra, N. K. (2010). Marketing Research An Applied Orientation Global Edition (6th ed.). New Jersey: Prentice Hall.

Selang, C. A. (2013). Bauran pemasaran (Marketing Mix) Pengaruhnya Terhadap Loyalitas Pelanggan Pada Fresh Mart Bahu Mall Manado. Jurnal $E M B A$, Universitas Sam Ratulangi Manado. Manado. Vol 1 No.3,pp:7180.

Sugiono. (2008). Metode Penelitian Kuantitatif, Kualitatif dan $R \& D$. Bandung: Alfabeta.

Sugiyono. (2014). Metode Penelitian Kuantitatif, Kualitatif dan $R \& D$. Bandung: Alfabeta.

Sukotjo, H., \& Sumanto, R. (2010). Analisa Marketing Mix 7P (Product, Place,
Promotion, Price, Partisipant, Process, dan Physical Evidence) Terhadap Keputusan Pembelian Produk Klinik Kecantikan Teta di Surabaya. Jurnal Mitra Ekonomi dan MAnajemen Bisnis, Universitas 17 Agustus. Surabaya. Vol 1 No.2,pp:216-229.

Sumarni, M., \& Soeprihanto, J. (2010). Pengantar Bisnis (Dasar-Dasar Ekonomi Perusahaan). Edisi ke 5. Yogyakarta: Liberty Yogyakarta.

Supomo, B. (2012). Metodologi Penelitian Bisnis. Yogyakarta: BPFE.

Tjiptono, Fandy. (2008). Strategi Bisnis Pemasaran. Yogyakarta: Andi 